\title{
Rejoinder to \\ Kalecki - a pioneer of modern macroeconomics by Jerzy Osiatyński
}

\section{Izabela Bludnik}

The aforementioned article by Jerzy Osiatyński provides the readers with an insight into the achievements of Michał Kalecki, one of the most outstanding Polish economists, whose work appears to be as up to date now as it was in the 1930s, when the Keynesian revolution was planting the roots of modern macroeconomics. Osiatyński focuses mainly on Kalecki's contribution to macroeconomic studies in the cyclical fluctuations and economic dynamics of the capitalist economy, recalling the impact that these have had on the evolution of heterodox Keynesianism.

It seems that this aspect is worth a little more consideration. Kalecki's works have been a source of inspiration for both Keynesian economists, especially Joan Robinson and Nicholas Kaldor and his numerous intellectual heirs, who brought about the birth of Post-Keynesian economics in the 1970s. Robinson treated Kalecki as a precursor of Keynesian economics. She believed that Kalecki created a much more logical and general version of the demand model than Keynes himself. Kalecki was better at analysing the issues of investment, price formation and income distribution in the short run and addressed the problems of capital accumulation and long-term economic change, which Keynes omitted. The Kaleckian function of consumption and savings included class division and its influence on the principle of effective demand, while Keynes focused on the anti-social behaviour of individuals. Social conflict also became the core of the Kaleckian inflation models, where the real (rather than nomi-

\footnotetext{
${ }^{1}$ Poznań University of Economics and Business, Faculty of Economics, Department of Macroeconomics and Development Studies, al. Niepodległości 10, 61-875 Poznań, Poland, izabela.bludnik@ue.poznan.pl.
} 
nal) wage is the result of the struggle of formalized labour groups with employers. Finally, Kalecki integrated the issue of imperfect competition with its macroeconomic model, introducing, unlike Keynes's competitive perspective, the conditions of oligopoly. Kalecki's accomplishments, complementary with respect to the shortcomings in Keynes's aggregate demand and employment theory, provided the basis for the Post-Keynesian alternative to the neoclassical synthesis, attempting to fit the master's views into Walras's general equilibrium model (Bludnik, 2015, p. 28).

Kalecki, by presenting his reflections in the form of mathematical models, had a strong influence on such Post-Keynesian economists as Lawrence Klein and David Worswick [Holt \& Pressman, 2001, pp. 3-4; Toporowski, 2003, pp. 227-228]. It was also important for the macroeconomic theory to refer to Kalecki's macroeconomic stock-flow approach, mentioned by Osiatyński. This gave rise to Wynne Godley's creation of the Post-Keynesian stock-flow consistent (?) model. This construction is extremely popular with Post-Keynesian economists and is the starting point for, inter alia, the monetary circuit theory, associated with Marc Lavoie and Louis-Phillipe Rochon. Drawing from the achievements of Keynes, Kalecki and the French-Italian circuit school, the proponents of the monetary circuit theory analyse the functioning of the whole economy through the prism of money circulation - from its endogenous creation through the banking system, through the payments made between particular social groups, to its final liquidation, which occurs at the time of the repayment of loans taken at the beginning of the cycle.

However it is important to emphasize that not all Post-Keynesian economists share their enthusiasm for the integration of the achievements of Keynes and Kalecki. One of the greatest critics of Kalecki's economics is Paul Davidson. He negated, above all, the model of income distribution based on the monopolisation of the economy. In his view Keynesian theory was of a truly general nature, inter alia, because the conclusions it made did not depend on the degree of competition or the monopolisation of the economy. Keynes clearly stated that his theory is applicable for every level of competition and therefore included in the analysis a perfectly competitive market with flexible prices and wages, showing that even in the absence of any market imperfections the equilibrium with unemployment is still possible. If it was not, then - according to Davidson - Keynes' political recommendations would focus primarily on ways to remove market failures that prevent full price flexibility, rather than on the nature of entrepreneurship in an uncertain, money-based economy.

Scepticism regarding the influence of Kalecki's works on the developments of Keynesian theory is also visible in the works of Victoria Chick [King 2002, p. 212]. In her many works on both Keynes's achievements and the directions of the evolution of Post-Keynesian thought, she never mentioned the role played by Kalecki (Bludnik, 2015, p. 28). 
Despite these critical positions, or rather omissions of Kalecki's achievements, it seems that his influence on modern macroeconomics has not been less profound than that of Keynes. Therefore it is difficult to argue with the position expressed in the paper, recognizing Kalecki as a pioneer of modern macroeconomics. What is more, due to the topicality of Kalecki's achievements, highlighted by Osiatyński, his pioneering works can help shed light on today's problems. As Toporowski stated [2013]: "In the 21st century we urgently need to revive the concept of Michał Kalecki and the principle of the circular flow of income as a keystone of macroeconomic analysis. In our 21st century development economy, we need to return to Kalecki's (but also Lange's) vision of the economic development of traditional societies: a vision that emphasizes economic development as a change in the social structure and not merely the empowerment of individuals."

\section{References}

Bludnik, I. (2015). Postkeynesizm. Teoria endogenicznej kreacji pieniądza, Poznań: Wydawnictwo Uniwersytetu Ekonomicznego w Poznaniu.

Holt, R. P. F., \& Pressman, S. (2001). What is post keynesian economics? In: R. P. F. Holt \& S. Pressman (Eds.), A new guide to post Keynesian economics, London: Routledge. King, J. E. (2002). A history of post Keynesian economics since 1936, Cheltenham: Edward Elgar.

Toporowski, J. (2003). Kaleckian economics, In: J.E. King (Ed.), The Elgar companion to post Keynesian economics, Cheltenham: Edward Elgar.

Toporowski, J. (2013). Powrót Kaleckiego, http://krytykapolityczna.pl/gospodarka/ toporowski-powrot-kaleckiego/2013/ 